\title{
ODDZIAŁ INSTYTUTU PAMIĘCI NARODOWEJ W BIAEYMSTOKU W PIERWSZYM ROKU SWOJEJ DZIAŁALNOŚCI
}

Ustawa Sejmu Rzeczypospolitej Polskiej z dnia 18 grudnia 1998 r. powołała do życia jedną z najważniejszych spośród nowych instytucji życia społeczno-publicznego w naszym kraju po 1990 r. - Instytut Pamięci Narodowej - Komisję Ścigania Zbrodni przeciwko Narodowi Polskiemu. Ustawodawca określił przy tym bardzo szeroko podstawowe zadania nowo utworzonego Instytutu. W myśl zapisu ustawy IPN ma obowiązek przede wszystkim gromadzenia i zarządzania dokumentami organów bezpieczeństwa państwa wytworzonymi od 22 lipca 1944 r. do 31 grudnia 1989 r.; prowadzenia śledztw w sprawie: zbrodni nazistowskich i komunistycznych; innych przestępstw stanowiących zbrodnie przeciwko pokojowi, ludzkości lub zbrodni wojennych; innych represji z motywów politycznych, jakich dopuścili się funkcjonariusze polskich organów ścigania lub wymiaru sprawiedliwości, albo osoby działające na ich zlecenie; a także szeroko ujmowanej działalności edukacyjnej i naukowej.

W praktyce Instytut rozpoczął swoją działalność pół roku później, tj. z chwila powołania w czerwcu 2000 r. na stanowisko Prezesa IPN prof. dr. hab. Leona Kieresa. Warto przy tym wiedzieć, że według ustawy prezes w sprawowaniu swojego urzędu jest niezależny od organów władzy państwowej. W ciągu następnych kilku miesięcy powołano dyrektorów 10 Oddziałów Instytutu we wszystkich miastach, w których funkcjonują sądy apelacyjne. 17 października 2000 r. nominację na stanowisko dyrektora Oddziału w Białymstoku odebrał z rąk Prezesa Instytutu profesor Uniwersytetu w Białymstoku dr hab. Cezary Kuklo, oraz dr hab. Edmund Dmitrów na stanowisko naczelnika Oddziałowego Biura Edukacji Publicznej. W tym czasie białostocki Oddział wraz z Oddziałową Komisją Ścigania Zbrodni 
przeciwko Narodowi Polskiemu (3 prokuratorów i sekretariat) mieścił się w trzech niewielkich pokojach użyczonych gościnnie przez Prezesa Sądu Okręgowego w gmachu przy ul. Mickiewicza 5. Przed dyrektorem Oddziału stanęło z jednej strony zatrudnienie pracowników, którzy obok prokuratorów mogliby rozpocząć realizację ustawowych zadań, w tym przejmowanie archiwaliów i udostępnianie dokumentów, prowadzenie edukacji publicznej i rzetelnych badań naukowych; $z$ drugiej stworzenie niezbędnej bazy materialnej.

Już pod koniec 2000 r. pracowało w Oddziale 18 osób (w tym 5 w pionie archiwalnym, $2 \mathrm{w}$ edukacji publicznej oraz 4 prokuratorów). Naczelnikiem Oddziałowego Biura Udostępniania i Archiwizacji Dokumentów został Eugeniusz Korneluk (dotychczasowy zastępca dyrektora Biblioteki Uniwersyteckiej w Białymstoku), zaś naczelnikiem Oddziałowej Komisji Ścigania Zbrodni przeciwko Narodowi Polskiemu - prokurator Radosław Ignatiew. Z kolei kierownictwo referatu Badań Naukowych i Zbiorów Bibliotecznych w OBEP objął doświadczony badacz dziejów najnowszych ziem północno-wschodniej Polski dr Jan Jerzy Milewski (od kilku lat Prezes Polskiego Towarzystwa Historycznego Oddziału w Białymstoku i redaktor „Biuletynu Historii Pogranicza”), a referatu Udostępniania w OBUiAD - Waldemar Franciszek Wilczewski (z Regionalnego Ośrodka Studiów i Ochrony Środowiska Kulturowego). W październiku 2001 r., a więc w rok od rozpoczęcia działalności Oddziału, zatrudnienie osiągnęło stan docelowy 71 osób (w tym 26 archiwistów, 10 historyków w pionie edukacji oraz 6 prokuratorów). Obowiązki kierowników referatów: Gromadzenia, Opracowania i Obsługi Magazynów oraz Ewidencji i Informacji w OBUiAD powierzono odpowiednio: Walentynie Oksiucie (dotychczasowemu zastępcy dyrektora Archiwum Państwowego w Białymstoku) i Wojciechowi Fedorowiczowi (przeszedł z Instytutu Historii UwB), zaś kierownika referatu Wystaw, Wydawnictw i Edukacji Historycznej w OBEP Ewie Rogalewskiej (wcześniej wieloletniemu pracownikowi Muzeum Podlaskiego). Jak zatem widać osoby z kadry kierowniczej charakteryzują się przede wszystkim dużym doświadczeniem zawodowym $z$ jednej strony, $z$ drugiej cieszą się one nienaganną opinią i szacunkiem w swoich poprzednich środowiskach pracy. Jednakże najliczniejsza grupę pracowników Oddziału, zwłaszcza w pionie archiwalnym, edukacji publicznej oraz administracji, stanowią młodzi ludzie, głównie absolwenci ostatnich paru lat studiów historycznych, prawniczych i filologicznych Uniwersytetu w Białymstoku.

Jednocześnie, wraz z rozszerzeniem terytorialnym właściwości działania Sądu Apelacyjnego w Białymstoku o znaczną część województwa warmiń- 
sko-mazurskiego we wrześniu 2001 r., rozpoczęto działania mające na celu uruchomienie Delegatury IPN w Olsztynie, podporządkowanej Oddziałowi w Białymstoku. Obecnie pracuje w niej już dwóch prokuratorów i dwóch archiwistów.

Równolegle $\mathrm{z}$ procesem naboru kadry (kandydatów do pracy zgłosiło się w sumie blisko 300) prowadzono we współpracy z władzami wojewódzkimi i miejskimi poszukiwania obiektu przeznaczonego na stałą siedzibę Oddziału. Biorąc pod uwagę rozmiary przewidywanej powierzchni magazynów archiwum (ok. $600 \mathrm{~m}^{2}$ ), pracowni naukowych, sali konferencyjno-wystawowej oraz docelowy stan zatrudnienia, znalezienie odpowiedniego budynku w centrum miasta było bardzo trudnym zadaniem. Ostatecznie, po wizjach lokalnych różnych obiektów, władze Instytutu w początkach 2001 r. zaakceptowały propozycję włodarzy miasta Białegostoku ulokowania Oddziału w gmachu położonym w dzielnicy Starosielce przy ul. Warsztatowej $1 \mathrm{~A}$. W wyremontowanym obecnie czteropiętrowym budynku $\left(1500 \mathrm{~m}^{2}\right)$ znalazły już swoje stałe pomieszczenia - co chcemy podkreślić - wszystkie trzy piony Oddziału: archiwalny wraz z magazynem, edukacyjny oraz komisja ścigania. Ta ostatnia $z$ chwila zakończenia drugiego etapu prac remontowych, przewidywanych na wczesną wiosnę 2002 r., przeprowadzi się do części niskiej obiektu, dzięki czemu warunki pracy prokuratorów ulegną dalszej zdecydowanej poprawie.

W związku z brakiem w pierwszych miesiącach większej powierzchni magazynowej, działalność Oddziałowego Biura Udostępniania i Archiwizacji Dokumentów koncentrowała się przede wszystkim wokół rozpoznania stanu materiałów archiwalnych instytucji (m.in. UOP, policji, sądów, prokuratur i innych), które z mocy ustawy zostały zobowiązane do przekazania dokumentów w skład zasobu archiwalnego Instytutu. Wspólnie z pracownikami wspomnianych instytucji pracownicy OBUiAD prowadzili segregację, inwentaryzację i sporządzali niezbędne pomoce ewidencyjno-informacyjne (komputerowe bazy danych). Od października 2001 r. rozpoczął się proces systematycznego gromadzenia zasobu archiwalnego w nowo wybudowanym magazynie. W chwili obecnej przejęto już nie tylko akta b. Okręgowej Komisji Badania Zbrodni przeciwko Narodowi Polskiemu, ale przede wszystkim archiwalia z Delegatury UOP w Białymstoku oraz akta Sądu Wojewódzkiego w Białymstoku, Łomży i Suwałkach, Sądu Rejonowego w Białymstoku i Giżycku, Prokuratury Wojewódzkiej w Białymstoku, Prokuratury Okręgowej w Olsztynie, Prokuratury Rejonowej w Białymstoku, Łomży, Giżycku, Olecku, Olsztynie (południe), Piszu, Aresztu Śledczego w Białymstoku, akta paszportowe Komendy Wojewódzkiej Policji Państwowej w Białymstoku. 
Ogółem w magazynach Oddziałowego Biura Udostępniania i Archiwizacji Dokumentów znajduje się już $\mathrm{w}$ tej chwili ponad $1720 \mathrm{mb}$ archiwaliów, a trzeba pamiętać, że jego zasób powiększa się systematycznie z każdym tygodniem.

Równocześnie $z$ pracami porządkowymi nad zasobem aktowym, od 7 lutego 2001 r. w nowych pomieszczeniach przekazanych archiwistom przez władze miejskie przy ul. Sienkiewicza 3, rozpoczęto akcję wydawania wniosków o udostępnienie dokumentów dotyczących wymierzonych przeciwko wnioskodawcom działań b. organów bezpieczeństwa państwa. Do końca listopada wydano 1057 takich wniosków i przyjęto 553 już wypełnionych (ok. $75 \%$ wnioskodawców zwróciło się we własnym imieniu, pozostali w sprawie osób najbliższych). Celem dotarcia do jak największej liczby osób pokrzywdzonych, często starych i schorowanych, zamieszkujących w znacznym oddaleniu od Białegostoku, podjęto decyzję o wy jazdach archiwistów z wnioskami do mniejszych miast. W tym celu pracownicy z OBUiAD dyżurowali w Ełku, Łomży, Olsztynie, Siemiatyczach i Suwałkach.

W siedzibie Oddziału zostały uruchomione pracownie naukowe, w których udostępniane są materiały archiwalne przede wszystkim do celów służbowych dla potrzeb prokuratorów i historyków z Biura Edukacji Publicznej. Do celów naukowo-badawczych udostępniane są w pierwszym rzędzie akta z lat 1939-1945. Nieco później, tj. z chwilą opracowania, zostaną udostępnione także akta organów bezpieczeństwa państwa wytworzone w okresie PRL. Dokumenty zawierające informacje niejawne będą udostępniane dopiero z chwilą ich odtajnienia. Warto także dodać, że od połowy września 2001 r. pierwszych siedem wytypowanych osób (brano pod uwagę przede wszystkim podeszły wiek i zły stan zdrowia) zapoznało się ze swoimi „teczkami".

Oddziałowe Biuro Udostępniania i Archiwizacji Dokumentów na bieżąco realizu je także kwerendy oraz zapytania od instytucji i osób fizycznych przede wszystkim do celów odszkodowawczych - dla sądów, różnych fundacji kombatanckich, emerytalnych, rentowych i innych.

Pomimo niezbyt licznej obsady pionu śledczego Oddziału (tylko 6 prokuratorów) podjął on ściganie w sprawach prowadzonych wcześniej przez Okręgową Komisję Badania Zbrodni przeciwko Narodowi Polskiemu, a zawieszonych $\mathrm{z}$ braku istnienia IPN, oraz spraw co do których zaistniały uzasadnione przesłanki popełnienia zbrodni wymienionych $\mathrm{w}$ ustawie o IPN z 18 XII 1998 r. Obok wszczętych śledztw zbrodni nazistowskich, dotyczących współudziału w popełnieniu w dniu 10 lipca 1941 r. w Jedwabnem zabójstw osób narodowości żydowskiej i zabójstw w dniu 7 lipca 1941 r. w Ra- 
dziłowie także osób narodowości żydowskiej, prokuratorzy białostoccy prowadzą również kilkanaście innych śledztw dotyczących powyższych zbrodni. Można tu wymienić chociażby śledztwa w sprawie zabójstw ludności cywilnej w okresie od 1941 r. do 1944 r. w Porzeczu. Osobną dużą grupę stanowią śledztwa komunistyczne, wśród których znajdują się m.in. śledztwa w sprawie przesiedlenia obywateli RP w okresie od 17 września 1939 r. do 22 czerwca 1941 r. z dawnych Kresów Wschodnich w głąb ZSRR i w sprawie przesiedlenia ludności cywilnej okupowanego obszaru regionu białostockiego w głąb ZSRR w wyżej wymienionym okresie. Z pewnością opinia publiczna nie tylko w kraju, ale i za naszą wschodnią granicą będzie zainteresowana wynikami śledztwa w sprawie zabójstwa ok. 300 wojskowych i cywilnych obrońców Grodna we wrześniu 1939 r., dokonanego przez żołnierzy sowieckich i funkcjonariuszy NKWD (przesłuchano blisko 80 świadków), w sprawie zabójstw 22 osób narodowości polskiej dokonanych w dniach 22 i 23 września 1939 r. w Lerypolu i Budowli, powiat grodzieński, czy śledztwa w sprawie zamordowania w dniu 9 listopada 1943 r. w Rejmontówce i Lubieszowie, pow. Kamień Koszyrski, woj. poleskie, ok. 200 osób narodowości polskiej. Dotychczas przeprowadzone czynności nie pozwalaja na jednoznaczne ustalenie, czy sprawcami tej ostatniej zbrodni była zorganizowana formacja UPA, czy też miejscowi Ukraińcy. Jednocześnie w wyniku nowej właściwości miejscowej prac Oddziałowych Komisji Ścigania Zbrodni przeciwko Narodowi Polskiemu część śledztw prowadzonych do tej pory w Białymstoku, jak np. w sprawie przesiedleń obywateli RP z tzw. Kresów Wschodnich na teren ZSRR, czy w sprawie zamordowania Polaków w Rejmontówce i Lubieszowie, przekazano do poszczególnych OKŚZpNP.

Dodajmy, że szereg innych śledztw dotyczy bezprawnego stosowania represji i niedozwolonych metod śledczych przez funkcjonariuszy PUBP w Białymstoku, Sokółce, Grajewie. W jednej z nich skierowano 2 akty oskarżenia do Sądów Rejonowych. W obu przypadkach została oskarżona ta sama osoba, która dopuściła się zbrodni komunistycznych jako funkcjonariusz PUBP. Wobec dwóch innych funkcjonariuszy byłego MBP sporządzono postanowienia o przedstawieniu zarzutów. Warto tutaj odnotować także śledztwo w sprawie bezprawnego pozbawienia wolności połączonego ze szczególnymi udręczeniami Aleksandra Rybnika i innych 23 członków Zrzeszenia „WiN", skazanych wyrokiem WSR w Białymstoku w dniu 20 lipca 1946 r.

W sumie w Oddziałowej Komisji Ścigania Zbrodni przeciwko Narodowi Polskiemu prowadzono (do końca października 2001 r.) 47 śledztw, w tym 35 dotyczących zbrodni komunistycznych i 11 zbrodni nazistowskich. 
Ponadto prokuratorzy przeprowadzili kilkadziesiąt postępowań sprawdzających i przesłuchali do końca listopada 2001 r. blisko 480 świadków. Jednocześnie prokuratorzy z Delegatury w Olsztynie podjęli już w chwili obecnej 15 postępowań w sprawie zbrodni komunistycznych.

Niemniej intensywne prace realizowali historycy z Oddziałowego Biura Edukacji Publicznej. W ramach udziału w projektach badawczo-edukacyjnych o zasięgu ogólnopolskim - Procesy i więźniowie polityczni 1944-1956prowadzono rozległe kwerendy w archiwum Sądu Okręgowego i w Archiwum Państwowym mające dostarczyć danych do Listy represjonowanych z przyczyn politycznych, w wyniku których sporządzono listę 275 osób skazanych w latach 1946-1955 przez Sąd Rejonowy w Białymstoku. Przystąpiono zarazem do sporządzania ankiet osobowych osób skazanych na karę śmierci. Z kolei w ramach projektu Stownik biograficzny uczestników antykomunistycznej konspiracji, opozycji i oporu spotecznego 1944-1956 opracowano ponad 20 biogramów. Wraz z systematyczną rozbudową stanu osobowego OBEP było możliwe podjęcie również badań nad historią stanu wojennego na terenie dawnych województw białostockiego, suwalskiego i łomżyńskiego w ramach projektu Stan wojenny - spojrzenie po latach (kwerendy archiwalne, zapoznawanie się z zachowanymi i nagrywanie nowych relacji). Podsumowaniem dotychczasowych działań i zarazem prezentacja nowych ustaleń badawczych w tym obszarze jest specjalnie przygotowywana na grudzień 2001 r. wystawa i konferencja naukowa. Wystawa, składająca się z dwóch części tematycznych wyodrębnionych tytułami: Solidarność i Wojna, prezentuje dokumenty, fotografie, filmy, plakaty, druki ulotne, tzw. literature drugiego obiegu, maszynę drukarską wraz z matrycami, malarstwo, grafikę, rzeźbę oraz tzw. biżuterię patriotyczną kojarzące się ze stanem wojennym i pochodzące ze zbiorów wielu prywatnych osób oraz instytucji. Warto podkreślić, iż w jej otwarciu 11.12.2001 r. udział wzięło kierownictwo IPN-KŚZpNP: Prezes Instytutu, prof. dr hab. Leon Kieres, Wiceprezes i Dyrektor Głównej Komisji Ścigania Zbrodni przeciwko Narodowi Polskiemu, prof. dr hab. Witold Kulesza oraz Wiceprezes Janusz Krupski.

Dużo uwagi i czasu białostoccy historycy poświęcili realizacji innego projektu centralnego - Zagtada Żydów na ziemiach polskich. Szczególną uwagę zwrócono na badania dotyczące mordu popełnionego na obywatelach polskich narodowości żydowskiej latem 1941 r. w Jedwabnem i innych miejscowościach w okolicach Łomży. Obok kwerend bibliotecznych i archiwalnych zarówno w kraju, jak i za granica (archiwa w Białymstoku, Warszawie, Łomży, Mińsku, Grodnie, Ludwigsburgu i Freiburgu), zbierano relacje oraz dokumentację prasową. $\mathrm{W}$ rezultacie przygotowano dwa opracowania 
(autorstwa E. Dmitrówa i J. J. Milewskiego) do Białej Księgi o roboczym tytule Wokót Jedwabnego.

Dużym echem - co warto podkreślić - odbiła się pierwsza międzynarodowa konferencja naukowa poświęcona Spoteczeństwu zróżnicowanemu narodowościowo w warunkach wojny. Poczatek wojny niemiecko-sowieckiej w 1941 r. i losy ludności cywilnej, zorganizowana przy współpracy z Oddziałem PTH i Ośrodkiem Doskonalenia Nauczycieli w czerwcu 2001 r. Obok historyków $z$ różnych krajowych ośrodków naukowych wzięli w niej udział także uczeni z Litwy, Białorusi i Ukrainy. Zarówno słuchacze, dyskutanci jak i referenci zgodnie akcentowali wysoki poziom naukowy spotkania i potrzebę jego kontynuacji. Z kolei w listopadzie 2001 r. odbyło się seminarium również o zasięgu międzynarodowym na temat Źródta $i$ stan badań nad dziatalnościq aparatu represji wobec podziemia niepodlegtościowego w latach 1944-1956 na pograniczu polsko-biatorusko-litewskim. Wygłoszone w trakcie jego trwania referaty ukazały nie tylko podobieństwa i różnice w organizacji aparatu represji (w tym także w latach 1939/40-1941), kadry i ich strukturę narodowościową, współdziałanie różnych jednostek aparatu, ale także rolę i wpływ czynników sowieckich na lokalny aparat bezpieczeństwa, sprawę więzień, obozów i miejsc straceń oraz różne metody zwalczania podziemia niepodległościowego (w tym wielkość i rodzaj zaangażowanych sił, oddziały pozorowane). Oba spotkania naukowe były dobrą okazją do konfrontacji cech procesów szeroko rozumianej sowietyzacji społeczeństw z obszaru Europy środkowej i wschodniej w latach wojny i po jej zakończeniu.

Obok prac naukowo-badawczych prowadzono również popularyzację wiedzy historycznej wśród nauczycieli i edukację historyczną młodzieży. Wspólnie $z$ centralą BEP zorganizowano w Tykocinie warsztaty przedmiotowo-metodyczne dla nauczycieli ze szkół z części b. woj. łomżyńskiego. Pracownicy OBEP przygotowali dwa referaty oraz pakiet edukacyjny dotyczący dziejów woj. białostockiego w okresie II wojny światowej. Przeprowadzono prelekcje dla młodzieży szkół średnich, a ponadto opracowano konspekty lekcji muzealnej i przekazano je szkołom. Drugie, tym razem dwudniowe warsztaty, odbyły się w październiku 2001 r. najpierw w Białymstoku, a następnie w Łomży i Suwałkach. Przebiegały one pod hasłem Polacy, Żydzi, Biatorusini i Litwini 1941-1945. Problemy narodowościowe w nauczaniu historii regionalnej. Nauczyciele historii szkół średnich wysłuchali kilku interesujących wykładów przygotowanych przez pracowników OBEP oraz wzięli udział w opracowaniu scenariusza zajęć dydaktycznych dla uczniów i materiałów metodycznych we współpracy z kolegami z Ośrodka Doskonalenia Nauczycieli w Białymstoku. Trzeba przy tym zauważyć, że niektóre z refe- 
ratów, jak np. prezentujący politykę okupantów, PKWN oraz Rządu Tymczasowego wobec ludności białoruskiej wywołały ożywioną, nie pozbawioną akcentów polemicznych dyskusję.

W chwili obecnej trwaja również przygotowania do wydania pakietu edukacyjnego poświęconego dziejom podziemia niepodległościowego na Białostocczyźnie. Obejmie on lata 1944-1956 i będzie dużą pomocą w prowadzeniu zajęć dotyczących historii regionalnej oraz dziejów najnowszych Polski. Nauczyciele i uczniowie będą mogli znaleźć w nim między innymi interesującą bazę źródłową oraz krótkie biogramy kilkudziesięciu osób działających w opozycji antykomunistycznej na obszarze naszego regionu. Pakiet będzie dostosowany do wykorzystania podczas zajęć lekcyjnych.

Podjęto także kroki celem nawiązania ściślejszej współpracy ze środowiskami kombatanckimi. W przededniu 62 rocznicy wybuchu II wojny światowej i Dnia Weterana Walk o Niepodległą Polskę kierownictwo Oddziału IPN gościło blisko 30-osobową grupę przedstawicieli organizacji kombatanckich z Białegostoku, Łomży i Suwałk. Dyrektor Oddziału podkreślił, że celem IPN jest oddanie sprawiedliwości tym, którzy od 1939 r. walczyli o wolną Polskę i przywracanie społeczeństwu prawdy historycznej, zakłamywanej w okresie ostatnich kilkudziesięciu lat. Z kolei kombatanci w bardzo bezpośredniej rozmowie wskazywali na wiele problemów nurtu jących ich środowiska, a które powinny zostać jak najszybciej zrealizowane, m.in. przyspieszenie procesu odtajniania akt służb specjalnych, pozbawienie kierowniczych stanowisk osób związanych $z$ dawnym aparatem represji, ustalenie miejsc pochówków skrytobójczych mordów UB i ich upamiętnienie.

Historycy z OBEP angażowali się również w wiele innych jeszcze działań. Dla przykładu warto wymienić ekspertyzy historyczne opracowane na zlecenie Sądu Rejonowego w Białymstoku, czy udział przedstawiciela IPN w pracach ekshumacyjnych prowadzonych przez Fundację „Pamięć” na terenie b. niemieckiego cmentarza wojskowego przy ul. Świerkowej. To ostatnie było o tyle ważne, że docierały do nas sygnały o możliwości zlokalizowania na tym terenie pochówków ofiar represji z lat 1944-1956. Jednakże z obserwacji przebiegu powyższych prac ekshumacyjnych wynika, że nie natrafiono na szczątki ludzkie, co do których istniałoby podejrzenie, iż należą do ofiar represji aparatu bezpieczeństwa $\mathrm{z}$ okresu stalinowskiego.

Pracownicy OBEP zasiadają licznie także w gremiach różnych komisji naukowych, zarówno zagranicznych jak i krajowych (m.in. ds. podręczników), w jury Olimpiady Historycznej i wielu innych konkursów. Cieszyć może fakt, że redaktorem naczelnym periodyku naukowego IPN „Pamięć i Sprawiedliwość” został E. Dmitrów, naczelnik białostockiego OBEP, 
a w jego radzie programowej zasiada C. Kuklo - dyrektor białostockiego Oddziału.

Dodajmy na koniec, że dzięki wysiłkom pracowników OBEP mieszkańcy, a zwłaszcza młodzież szkolna Augustowa, Bielska Podlaskiego, Grajewa, Łomży, Suwałk i stolicy naszego województwa mogła zapoznać się z bardzo interesującą wystawą edukacyjną Grudzień 70. Gdańsk-Gdynia.

Nie mniej ambitnie wyglądają najbliższe zamierzenia badawcze, edukacyjne i wystawiennicze historyków białostockiego Oddziału IPN. Głównym problemem badawczym realizowanym w 2002 r. będzie Struktura $i$ metody dziatania aparatu bezpieczeństwa Polski Ludowej w l. 1944-1956, w wyniku których ma powstać wstępny raport dotyczący WUBP w Białymstoku w 1. 1944-1956 oraz jednego z powiatowych UBP. W październiku 2002 r. planowane jest seminarium na temat działalności aparatu represji $\mathrm{z}$ udziałem historyków białoruskich i litewskich. Będziemy także badać metody walki aparatu bezpieczeństwa $\mathrm{z}$ podziemiem - przewidujemy organizację sesji naukowej na temat: Podziemie niepodlegtościowe na Biatostocczyźnie 1944-1956. Ważny jest tu również temat szczegółowy, spotykający się ze szczególnym zainteresowaniem społecznym: Los mieszkańców Suwalszczyzny zaginionych w obtawie lipcowej 1945 r.

W działalności wystawienniczej planowane jest eksponowanie wystawy Stan wojenny - spojrzenie po 20 latach w pierwszym półroczu 2002 r. w Augustowie, Drohiczynie, Bielsku Podlaskim, Zambrowie. Ponadto zostaną przygotowane dwie dalsze ekspozycje: Ludność Białostocczyzny pod okupacja sowiecka 1939-1941 oraz Życie codzienne na okupowanej Biatostocczyźnie 1939-1945.

Ten krótki przegląd rocznej działalności Oddziału Instytutu Pamięci Narodowej w Białymstoku wskazuje, że pomimo trudnych warunków lokalowych, ale przy ogromnym zapale i zaangażowaniu osób, można było realizować - naszym zdaniem $z$ dużym powodzeniem - wszystkie statutowe cele zawarte w ustawie sejmowej o Instytucie Pamięci Narodowej. Nawiązana zaś ostatnio ściślejsza współpraca z Polskim Radiem Białystok, a w najbliższej przyszłości - mamy taką nadzieję - także z telewizją i lokalną prasą przybliży w jeszcze szerszym stopniu niż dotychczas codzienną pracę prokuratorów, archiwistów i historyków białostockiego oddziału IPN. 